\title{
Guide to the Compact Disc Rara!
}

тRACK 1. “Jan, Men Kouto” (Jean, Here Is Your Knife). 52 sec. A Rara colonel sang this a cappella song that speaks of militarism and preparedness. It is recorded here without chorus.

тRACK 2. "Instrumental from Rara Se Malè." 2 min. The Rara was playing on the side of the road in Beaufort, in the Artibonite Valley, on Good Friday I993. This track shows the "heat" of the drums and horns (vaksin, konè, and kès) in full swing. See discussion on pages I9-2I.

тrACк 3. "Kay Ile" (The House of Ile). 2 min., 5 sec. This is an ochan (salute song) sung in Fermathe on Easter weekend I992. The Rara had stopped in front of a Vodou temple in order to collect money. See discussion on pages $26-30$ and $50-52$.

тваск 4. "Instrumental Isolations.” 3 min., 29 sec. Rara La Belle Fraîcheur de l'Anglade. After the Rara saluted the Vodou temple recorded in track 3, they stopped to play in place. I made the recording by moving among the musicians, capturing first one group and then another. You can clearly hear the various instruments: kès (drum), graj (scraper), high and bass vaksin (bamboo tube), and finally a bit of chorus. The whistle is directing the dancers, who are performing for the Vodou priest. See discussion on pages I9-2I and 26-30.

TRACK 5. "Notre Dame de 7 Doleurs." 3 min., 45 sec. This ceremony was recorded in Bourg Champagne in I978 at 9:30 A.M., inside a Vodou temple before the drawing of the vèvè (ritual designs made on the floor). A Vodou priest leads the singing, and you can hear many religious songs: "Ouve Baye Pou Djab-La” (Open the way for the spirit), and "Gwo Lwa, Gwo Pwen, Simbi

\footnotetext{
All tracks recorded by Elizabeth McAlister with assistance from Phenel Colastin except those indicated. Used by permission. This CD was recorded in Haiti by Elizabeth McAlister and produced at Wesleyan University by Holly Nicolas, who had been present at some of the recording in Haiti in I993. Mixing and mastering was carried out by Peter Hadley of the music department at Wesleyan University using a Macintosh computer and Soundedit computer software.

"Recorded by Verna Gillis and released on Caribbean Revels: Haitian Rara and Dominican Gaga (Smithsonian Folkways). Used by permission.
} 
Nan Dlo" (Great spirit, great “point,” Simbi-of-the-water). See discussion of religion in Rara in chapters 3 and 4.

тrack 6. "Kwiy Nan Men, M'ap Mande... al Roule Tete.” I min., 55 sec. This Vodou song says, "Bowl in my hand, I am begging, but it's a spirit I am seeking." Then the chorus launches into the vulgar ditty, "Go roll your mother's titties." You can hear how tired the voices are; it is late in the day. See discussion in chapter 2, especially page 62.

track 7. “Tripotay Fanm Pi Rèd Pase Wanga” (Women's Gossip Is Worse Than Magic). I min., $27 \mathrm{sec}$. The chorus is well balanced with the instruments in this recording.

TrACK 8. "Fre Dieuvè Pa'p Mande Prete" (Brother Dieuve Will Not Be Asking to Borrow This Year). 54 sec. This is an original song by Rara La Belle Frầcheur de l'Anglade that boasts about the good fortunes of their president, Fre Dieuve. The chorus sang the song for me without instruments. See discussion in chapter 5 , especially pages $142-45$.

тrack 9. “Fre Dieuvè Pa'p Mande Prete.” I min., 44 sec. Easter Sunday 1992. This is the same song as on track 8, with the addition of the full Rara orchestra, out on parade. You can hear the graj particularly well.

track 10. "M'ap Antre ak Tout Kò Divisyon Mwe, Osay O” (I Am Arriving With My Regiment, Ossagne Oh). 2 min., 4 sec. Easter Sunday 1992. This ochan is probably derived from European signal corps drumming style. See pages $50-52$ and 135 and the discussion of militarism in chapter 5 .

TRACK 11. "Grosè Bagay sa, Mwen Pa Kapab Ankò" (The Size of That Thing-I Can't Deal with It). 2 min., I 5 sec. Rara Ya Seizi, Verettes, Holy Saturday I993. The ostinato (melody tag) of this Rara had words that were not sung here. See page 46 , chapter 2 , and page 145 .

тrack 12. "Pa Gen Fanm Konfyans" (There Are No Trustworthy Women). 2 min., 47 sec. Rara Bann Bourgeois de la Lwa, Pont Sonde, Good Friday I993. This charyio-pye (foot-stomping) Rara creates rhythm by their stomping feet. You can hear cars passing on the roadway. See discussion on pages $45,64-$ 66 , and $145-46$.

тrack 13. "Pa Vle Zenglendo" (We Don't Want Criminals). 3 min., 44 sec. Rara Modèl, Port-au-Prince, Easter Monday I993. The words to this melody were commonly known but were not sung in times of repression. Instead, the banbou (bamboo tube) stood in for the lyrics. The Rara recorded here was returning to the Vodou temple from the season; you can hear the whip cracking. See discussion of zenglendo on pages $176-77$ and whips on page I०8. The chorus is singing "Sodo m'prale" (I'm leaving for Sodo), a song that became politicized during the coup; see discussion on pages $175-77$.

"Recorded by Elizabeth McAlister and featured on Rhythms of Rapture: Sacred Musics of Haitian Vodou (Smithsonian Folkways). Used by permission. 


\section{Guide to the Compact Disc / xvi i}

TRACK 14. "Cemetery at Bizoton.” 6 min., 53 sec. This track was recorded in I 978 in the cemetery at Bizoton, one of the neighborhoods just outside downtown Port-au-Prince. You can hear four vaksin, a whistle, and the distinct sound of a flute, as well as three konè and drum. The group was leaving the cemetery after a midnight ceremony. Finished with their important religious work, the Rara sang the "vulgar" and sexualized betiz songs that are the discursive domain of the Gede spirits. Working the cemetery is discussed in chapter 3, and betiz are discussed in chapter 2.

тr Aск 15. "M'Pap Mache a Tè” (I Don't Walk on the Ground). I min., I 3 sec. La Belle Fraîcheur de l'Anglade sang this boasting song about one of their leaders, Dieuvè, whose Rara was like a plane and allowed them to fly above the ground. The second song on the track talks about barring "whores" from the area; see discussion on page 66.

track 16. "Jan Dantò Ki Voye Yon Lèt Pou Mwen Pou'm Al O Zaye" (Jean Dantor Sent a Letter for Me to Go to Zaire). 2 min., 2 I sec. This is a Petwo song used in Rara that may reference Zaire.

тRACк 17: “Guantanamo M'Rive” (I Ended Up in Guantanamo).** I min., 49 sec. Rara Inorab Kapab, Citè Soleil, March I993. This Rara music is in the style of Jéremie; its members moved from that southern coastal town to Portau-Prince. When they arrived in the capital, they found that making a living was still impossible. This song tells how they sold everything they had and left the country by boat but were returned from Guantanamo to Haiti to starve. Note that in the southern Rara style, typically there are about six vaksin but no drums. As usual in Rara, a sustainer rhythm is played on the side of the banbou with sticks, but here the only other percussion is a graj. See discussion on pages $40-42$.

тrAск 18. "Kalfou." 5 min., I 7 sec. This Rara from Léogâne features the distinct sound of that region, which often includes brass such as trumpets and trombones. The vaksin are played here by humming into them, producing a sound distinct from that in other regions, where they are hocketed (alternated) in blown tones.

TRACK 19. "Instrumental by Rara Se Malè." 2 min., 35 sec. Beaufort, Good Friday 1993. This track features a "hot" performance by the high-pitched vaksin.

TRA C к 20. "Bann Sanpwèl-la nan Lari-a” (The Chanpwèl Band Is in the Streets). I min., 3 I sec. Rara Delin, Tomasin, I992. This Rara was also a Chanpwèl (secret society) band; the lyrics say, "The Chanpwèl band is in the streetsWhat will I give them?" See discussion of Chanpwèl in chapter 3 and on pages I $40-45$.

\footnotetext{
* Recorded by Verna Gillis and released on Caribbean Revels. Used by permission.

* Recorded by Elizabeth McAlister and featured on Rhythms of Rapture. Used by permission.
} 
TrACK 21. "Mwen Antre Nan Lakou-a; Kote yo?" (I'm Entering the Compound; Where Are They?). 2 min., 5 sec. Rara La Belle Fraîcheur de l'Anglade, Fermathe, Easter 1992. The Rara band was entering a Vodou temple and preparing to ask for a contribution. See related discussion on pages I66-67.

track 22. "Yo Vin Gade'm Pou Yo Pote'm Ale" (They're Coming To Watch Me and Take Me Away). 3 min., 32 sec. Rara La Belle Fraîcheur de l'Anglade, Fermathe, Easter I 992. The call and response singing of this Rara's original song is easy to hear on the track. The song displays the fearfulness and paranoia of some Vodou songs. See discussion on pages I 7 I-74.

TRACK 23. “Instrumental from Rara Se Malè.” I min., I 4 sec. Artibonite, Good Friday I993. The melody of the vaksin almost sounds like a slow bolero. You can hear the band "break" almost like a Brazilian samba band.

тrACк 24. “Mama'm Sere Zozo'm” (My Mother Hid My Dick). 2 min. Rara Modèl, Port-au-Prince, Easter Monday I993. This Rara was slowly heading toward home, finishing up the season by singing vulgarities: "My mother put away my dick so I won't screw whores. If I screw I'll get AIDS-go fuck your mother." The band's lyrics combined absurdity, vulgarity, and AIDS awareness. See discussion of sex and politics in chapter 2 . 
This page intentionally left blank 


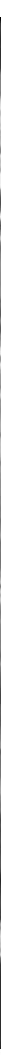

Rara kolonèl in the Artibonite set off with whips in hand (photo (c) Chantal Regnault) 